\title{
Random amplified polymorphic DNA (RAPD) finger prints evidencing high genetic variability among marine angiosperms of India
}

\author{
ELANGOVAN DILIPAN ${ }^{1}$, JUTTA PAPENBROCK ${ }^{2}$ AND THIRUNAVAKKARASU THANGARADJOU ${ }^{1, *}$ \\ ${ }^{1}$ Centre of Advanced Study in Marine Biology, Annamalai University, Parangipettai - 608 502, Cuddalore Dt., Tamilnadu, India, \\ ${ }^{2}$ Institute of Botany, Leibniz University Hannover, Herrenhäuserstr. 2, D-30419 Hannover, Germany, ${ }^{*}$ Present address: Science and \\ Engineering Research Board, New Delhi 110070.
}

\begin{abstract}
In India 14 seagrass species can be found with monospecific genera (Enhalus, Thalassia and Syringodium), Cymodocea with two species and Halophila and Halodule represented by more than two taxonomically complex species. Considering this, the present study was made to understand the level and pattern of genetic variability among these species collected from Tamilnadu coast, India. Random amplified polymorphic DNA (RAPD) analysis was used to evaluate the level of polymorphism existing between the species. Out of the 12 primers tested, 10 primers amplified 415 DNA fragments with an average of 41.5 fragments per primer. Of the total 415 amplified fragments only 123 (29.7\%) were monomorphic and the remaining 292 (70.3\%) were polymorphic for Indian seagrass species. Among the 10 primers used four are identified as the key primers capable of distinguishing all the Indian seagrasses with a high degree of polymorphism and bringing representative polymorphic alleles in all the tested seagrasses. From the present investigation, this study shows that the RAPD marker technique can be used not only as a tool to analyse genetic diversity but also to resolve the taxonomic uncertainties existing in the Indian seagrasses. The efficiency of these primers in bringing out the genetic polymorphism or homogeneity among different populations of the Halophila and Halodule complex still has to be tested before recommending these primers as an identification tool for Indian seagrasses.
\end{abstract}

Keywords: Marine angiosperm, genetic variability, RAPD, India

Submitted 6 July 2013; accepted 11 April 2016; first published online 19 May 2016

\section{INTRODUCTION}

The PCR-based RAPD marker technique is widely used for distinguishing genetic variation of populations at the individual level since it detects mutations in coding and non-coding regions of genomes (Kirsten et al., 1998), genetic mapping (Chalmers et al., 2001) and for identification of markers linked with desired traits (Bai et al., 2003). Assessment of the genetic variability of seagrasses has been attempted using a variety of techniques including isozyme analyses (McMillan \& Williams, 1980; McMillan, 1981, 1982; Laushman, 1993; Capiomont et al., 1996; Reusch, 2001), RAPD analysis (De Heij \& Nienhuis, 1992; Kirsten et al., 1998; Procaccini et al., 1999; Angel, 2002; Jover et al., 2003; Micheli et al., 2005), AFLP (Waycott \& Barnes, 2001), and microsatellites (Randall et al., 1994; Davis et al., 1999; Reusch, 2002; Reynolds et al., 2012). Isozyme analysis revealed only low diversity even over large geographic distances as it is less sensitive to genomic changes than the DNA markers, because they sample functional enzymes in coding regions

Corresponding author:

T. Thangaradjou

Email: umaradjou@yahoo.com that are relatively conserved evolutionarily (Nei, 1987); whereas DNA fingerprinting provides better resolution of genetic relationships as it assesses more loci than directly assaying the genome (Avise, 1994). RAPD, microsatellites and AFLP typically show higher levels of genetic variation than isozymes and are generally inexpensive to implement and require significantly less development time than most other methods for detecting genetic variation. Co-dominant nature and ensuring reproducibility (Clark \& Lanigan, 1993; Lambert \& Millar, 1995; Grosberg et al., 1996) are the only limitations of RAPD techniques.

RAPD markers have been successfully used to assess the pattern of genetic diversity and the genetic structure of rare plants and help in the conservation of endangered plants (Dong et al., 2010). The technique also helps track the longterm evolutionary history of species (shifts in distribution, habitat fragmentation and population isolation), mutation, genetic drift, mating system, gene flow and selection (Schaal et al., 1998). Patterns of genetic diversity in seagrasses are also influenced by other factors such as the spatial structure, age and maturity of the meadows, which affect the recruitment potential of seedlings, pollen and vegetative propagules. Despite all these points, RAPD has been successfully used to assess genetic diversity of seagrasses, this includes intrapopulation variability in Posidonia australis (Waycott, 
Table 1. Geographic location of the study areas.

\begin{tabular}{|c|c|c|c|}
\hline S. No. & Station name & Geographic location & Seagrass species \\
\hline 1 & Marakkaanam & $12^{\circ} 13^{\prime} 96.7^{\prime \prime} \mathrm{N} 79^{\circ} 58^{\prime} 77.2^{\prime \prime} \mathrm{E}$ & Halophila ovalis subsp. ramamurthiana \\
\hline 2 & Parangipettai & $11^{\circ} 29^{\prime} 30.5^{\prime \prime} \mathrm{N} 79^{\circ} 46^{\prime} 30.6^{\prime \prime} \mathrm{E}$ & Halophila beccarii Asch. \\
\hline 3 & Mallipattinam & $10^{\circ} 15^{\prime} 76.1^{\prime \prime} \mathrm{N} 79^{\circ} 19^{\prime} 24.1^{\prime \prime} \mathrm{E}$ & Cymodocea serrulata (R. Br.) Asch. \& Magnus \\
\hline 4 & Manora & $10^{\circ} 15^{\prime} 93.3^{\prime \prime} \mathrm{N} 79^{\circ} 18^{\prime} 60.3^{\prime \prime} \mathrm{E}$ & $\begin{array}{l}\text { Halodule pinifolia (Miki) Hartog., } \\
\text { Syringodium isoetifolium (Asch.) Dandy }\end{array}$ \\
\hline 5 & Sambaipattinam & $10^{\circ} 12^{\prime} 79.0^{\prime \prime} \mathrm{N} 79^{\circ} 16^{\prime} 95.2^{\prime \prime} \mathrm{E}$ & $\begin{array}{l}\text { Enhalus acoroides (L.F.) Royle., } \\
\text { Halodule wrightii Asch. }\end{array}$ \\
\hline 6 & Kattumaavadi & $10^{\circ} 07^{\prime} 79.5^{\prime \prime} \mathrm{N} 79^{\circ} 14^{\prime} 93.4^{\prime \prime} \mathrm{E}$ & $\begin{array}{l}\text { Thalassia hemprichii (Ehrenb.) Asch. } \\
\text { Halophila ovata Gaud., } \\
\text { Halophila decipiens Ostenf., } \\
\text { Halodule uninervis (Forsk.) Asch. }\end{array}$ \\
\hline 7 & Paasipattinam & $9^{\circ} 48^{\prime} 3 \mathrm{O}^{\prime \prime} \mathrm{N} 79^{\circ} 04^{\prime} 71^{\prime \prime} \mathrm{E}$ & $\begin{array}{l}\text { Halophila ovalis (R. Br.) Hook. } f \text {., } \\
\text { Halophila stipulacea (Forsk) Asch. }\end{array}$ \\
\hline 8 & Chinnapaalam & $9^{\circ} 16^{\prime} 14.5^{\prime \prime} \mathrm{N} 79^{\circ} 12^{\prime} 55.2^{\circ} \mathrm{E}$ & Cymodocea rotundata Ehrenb. \& Hempr.ex. Asch. \\
\hline
\end{tabular}

1998), high genetic homogeneity in Cymodocea nodosa from the Northern Atlantic (Alberto et al., 2001), genetic diversity of Cymodocea nodosa and P. oceanica populations in the Mediterranean Sea (Procaccini \& Mazzella, 1996), low degree of gene flow between populations in Zostera muelleri (Jones et al., 2008) and P. oceanica from Santa Marinella meadow (Rotini et al., 2011) among others. Furthermore, RAPD markers revealed a decreased genetic diversity in $P$. oceanica along the anthropogenic disturbance gradient, both on a small scale within a meadow and on a large scale in the Mediterranean Sea (Micheli et al., 2005). This gives an indication that these techniques can also be used to assess the health of the seagrass beds at any given time.

Reports are available on the use of molecular markers such as RFLP, AFLP and microsatellites to estimate the genetic diversity of seagrasses, however, these are co-dominant markers, and analyse one locus at a time. RAPD markers are one of the most popular approaches (Martin \& Hernandez, 2000) and dominant markers can amplify many loci (Chalmers et al., 2001) at a time. Although the technique was largely used to uncover genetic diversity among populations, gene flow from different populations, etc., researchers alternatively used this technique to investigate the genetic diversity of a single population of different genera. Lucas et al. (2012) is the only gene-based study available on Indian seagrasses to date. Studies on Orchidaceae (Lim et al., 1999), Verbenaceae (Viccini et al., 2004) Musa spp. (Das et al., 2009), Apocynaceae (Mahmood et al., 2011) and Cyprinidae (Callejas et al., 2004) are the few classic examples. Considering the non-availability of RAPD datasets for Indian seagrasses, the present study aimed to discriminate the genetic variability among the Indian seagrasses by using the RAPD technique and to standardize the technique for population level studies in future.

\section{MATERIALS AND METHODS}

\section{Collection and selection of taxa}

Young seagrass (Enhalus acoroides, Thalassia hemprichii, Halophila ovalis, $H$. ovalis subsp. ramamurthiana, $H$. ovata, $H$. decipiens, $H$. stipulacea, $H$. beccarii, Cymodocea serrulata, C. rotundata, Halodule pinifolia, $H$. uninervis, $H$. wrightii and Syringodium isoetifolium) leaves devoid of any epiphytic overgrowth were collected from Tamilnadu coast. Care was taken to collect the samples from a single extension of the rhizome (Table 1). The identification and taxonomic status of the samples were confirmed using the keys for seagrasses (Den Hartog, 1970) and other local keys (Ramamurthy et al., 1992; Kannan \& Thangaradjou, 2006). Samples were washed thoroughly in seawater to remove debris and sediments and rinsed with double distilled water. Then the whole leaf material was cut and immersed in $\mathrm{NaCl} / \mathrm{CTAB}$ solution (Storchova et al., 2000) until the extraction of genomic DNA.

\section{PCR analysis by using RAPD markers}

Fresh leaves $(100 \mathrm{mg})$ of seagrass sample were extracted for Genomic DNA by using Plant Genomic DNA Minispin kit (Chromous Biotech, Code: RKTo7/08; Bangalore, India) according to the protocol supplied by the manufacturer. Twelve decamer RAPD primers of two series (A and K) obtained from Carl Roth $\mathrm{GmbH}$, Karlsruhe, Germany, were used for DNA amplification (Table 2). The PCR conditions were optimized for DNA concentration, the PCR reaction was performed in a Mastercycler gradient PCR (Eppendorf, Germany) with Red dye PCR master mix (GeNei, Cat:105908; Bangalore) in a total volume of $1 \times$ concentration of $12.5 \mu$ l reaction mixture by adopting the following PCR

Table 2. List of primers selected from Kit $\mathrm{A}$ and $\mathrm{K}$ used for the study.

\begin{tabular}{|c|c|c|}
\hline S. No. & Name of primer & Primer sequence \\
\hline 1 & $3003 \mathrm{~A}$ & $5^{\prime}-\mathrm{CAG}$ CAC CCA C-' 3 \\
\hline 2 & $3004 \mathrm{~A}$ & $5^{\prime}$-TCT GTG CTG G-' 3 \\
\hline 3 & $3006 \mathrm{~A}$ & $5^{\prime}-\mathrm{AGC}$ CAG CGA A- ${ }^{\prime} 3$ \\
\hline 4 & $3009 \mathrm{~A}$ & $5^{\prime}-\mathrm{CAA}$ ACG TCG G-' 3 \\
\hline 5 & $3010 \mathrm{~A}$ & $5^{\prime}$-GTT GCG ATC C-' 3 \\
\hline 6 & $5852 \mathrm{~A}$ & $5^{\prime}-\mathrm{TGC}^{-} \mathrm{CGA}$ GCT G-' 3 \\
\hline 7 & $5854 \mathrm{~A}$ & $5^{\prime}-\mathrm{AAT}$ CGG GCT G-' 3 \\
\hline 8 & $5858 \mathrm{~A}$ & $5^{\prime}-\mathrm{GTG}$ ACG TAG G-' 3 \\
\hline 9 & $5860 \mathrm{~A}$ & $5^{\prime}$-GTG ATC GCA G-' 3 \\
\hline 10 & $8053 \mathrm{~K}$ & 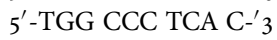 \\
\hline 11 & $8055 \mathrm{~K}$ & $5^{\prime}-\mathrm{AAG}$ TGC GAC C-' 3 \\
\hline 12 & $8061 \mathrm{~K}$ & $5^{\prime}-$ GTG TCG CGA G-' 3 \\
\hline
\end{tabular}


program: $5 \min 94{ }^{\circ} \mathrm{C}, 40$ cycles of 1 min at $94{ }^{\circ} \mathrm{C}, 1 \mathrm{~min}$ at $36{ }^{\circ} \mathrm{C}, 2 \mathrm{~min}$ at $72{ }^{\circ} \mathrm{C}$, followed by $5 \mathrm{~min}$ of the final extension at $72{ }^{\circ} \mathrm{C}$. The success of the PCR reactions was monitored by running $12.5 \mu \mathrm{l}$ of PCR reaction on $1 \%$ agarose (Himedia, Mumbai) in $1 \times$ TAE buffer ( $40 \mathrm{mM}$ Tris-acetate, $1 \mathrm{mM}$ EDTA) gel (ethidium bromide concentration $0.1 \mu \mathrm{g}$ per $1 \mathrm{ml}$ of gel) with $50 \mathrm{~V}$ applied voltage. DNA bands on the gel were visualized under UV light using Royal Intas Gelıx imager gel doc (Brandenburg, Germany).

\section{Data analysis of amplified profiles}

The electropherograms were manually converted into binary matrices reflecting the presence (1) or absence (o) of resulting alleles. The matrices were assessed by FreeTree software, ver. 9.1 using the Unweighted Pair Group Method with Arithmetic Mean (UPGMA) construction method. The similarity coefficient was calculated according to Nei and Li (1979) and the pairwise genetic distance according to Nei (1978). On the basis of the genetic distance among individuals, calculated as the average taxonomic distance using the similarity for interval data routine and principal coordinates analysis (PCoA) was performed with the average taxonomic distance in NTSYSpc $2.11 \mathrm{~L}$ software (Rohlf, 2000). The original matrix was resampled with 500 times bootstrap and a consensus tree was generated. All dendrograms were displayed and printed using TreeView software ver. 1.6 (Page, 1996). The percentage polymorphism was calculated by using the following statistics.

Per cent polymorphism $=$ Number of polymorphic bands/ Total number of bands $\times 100$

\section{RESULTS}

Seagrass species ( 14 belonging to six genera) from Tamilnadu coast, India were analysed using 12 RAPD primers, in order to select a set of RAPD primers which produces reliable and reproducible fingerprints for the Indian seagrasses. After the initial screening 10 primers were retained for assessment of the genetic diversity between the seagrass species while the primers $3004 \mathrm{~A}$ and $3006 \mathrm{~A}$ were left without any further analysis as they failed to show any significant genetic differences among different species. The reproducibility of all these markers was checked by performing at least two experiments per RAPD primer, in the event of inconsistency in results then the experiment was repeated again for consistency. The results from each RAPD product were assumed to represent a single locus and data were scored as the presence of these bands and compared with samples of different species. These 10 primers amplified 415 DNA fragments with an average of 41.5 fragments per primer. Of the total 415 amplified fragments only $123(29.7 \%)$ were monomorphic and the remaining 292 (70.3\%) were polymorphic (Table 3) in Indian seagrass species.

The maximum number of bands produced by a single primer $5852 \mathrm{~A}$ was 62 ranging 500 to $2500 \mathrm{bp}$ while the minimum of 25 bands with 500 to 2500 bp were amplified by the primer $8053 \mathrm{~K}$. The number of RAPD bands amplified by the remaining primers ranged between 32 and 55 fragments and alleles ranged from $\sim 300$ to $5000 \mathrm{bp}$ in length (Figures 1 and 2). A high percentage of polymorphism was

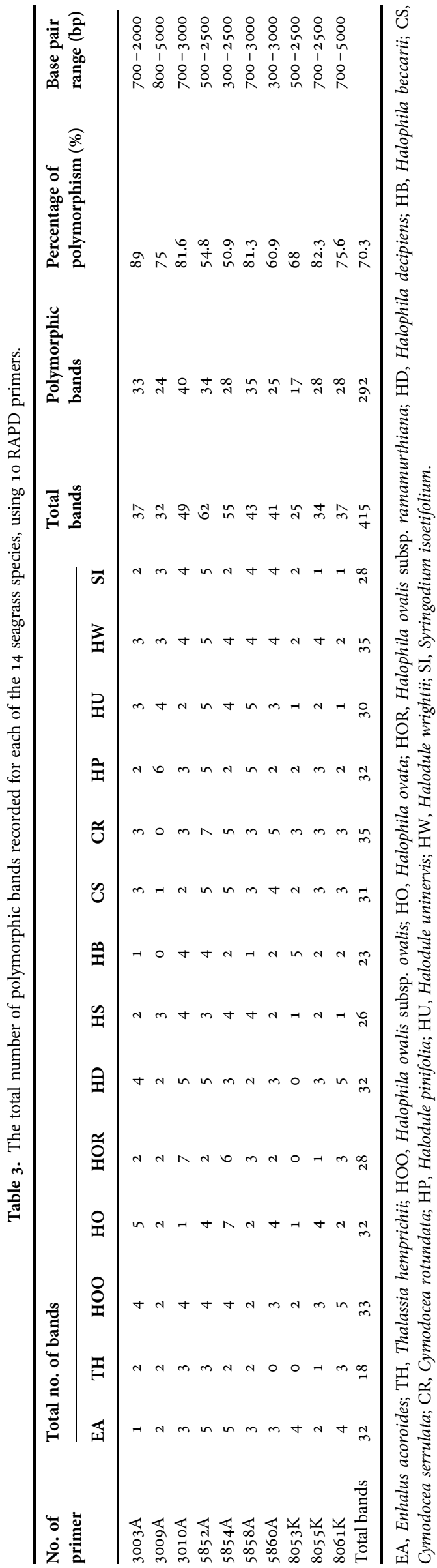




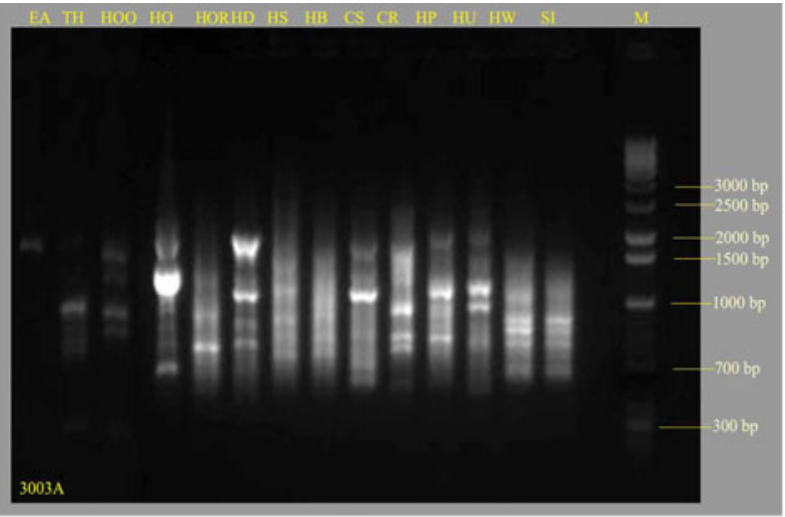

(a)

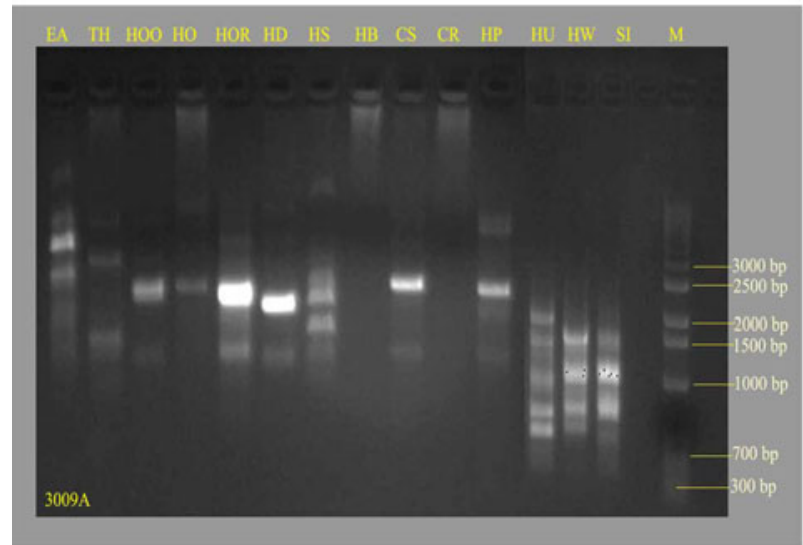

(b)

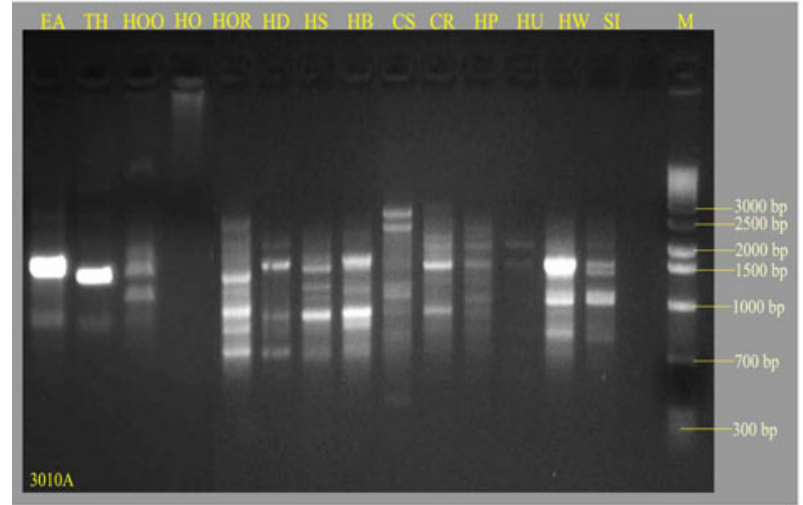

(c)

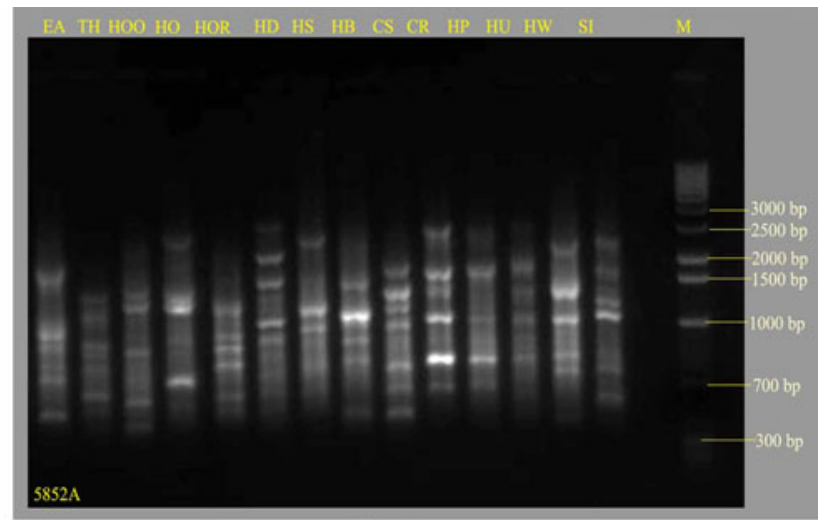

(d)

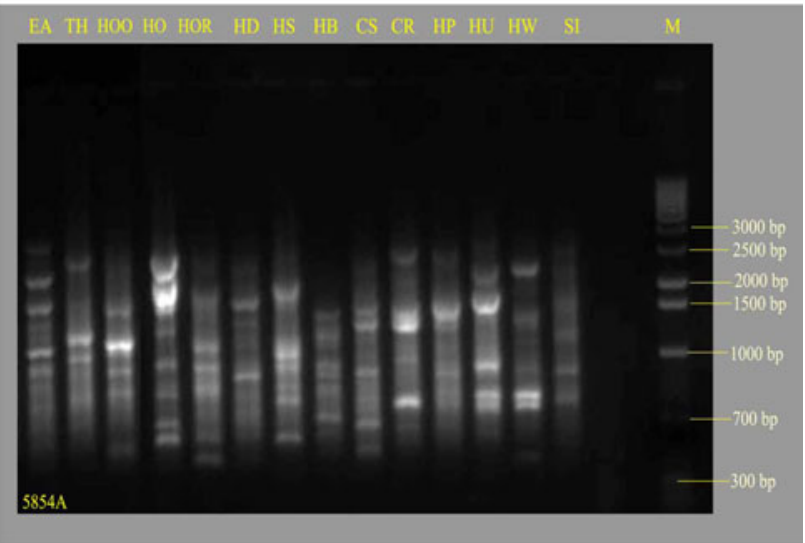

(e)

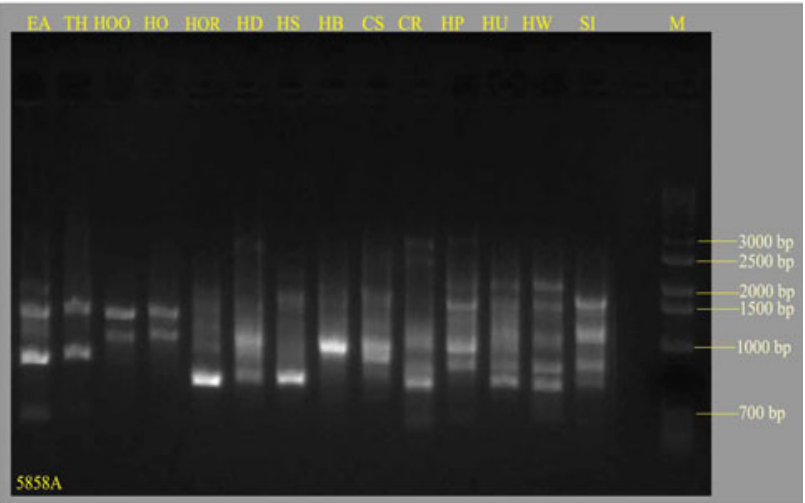

(f)

Fig. 1. The electropherogram of RAPD profiles for marine angiosperms of India using different primers: (A) 3003A, (B) 3009A, (C) 3010A, (D) 5852A, (E) $5854 \mathrm{~A},(\mathrm{~F}) 5858 \mathrm{~A}$.

observed with primers $3003 \mathrm{~A}, 8055 \mathrm{~K}, 3010 \mathrm{~A}$ and $5858 \mathrm{~A}$ with $89,82.3,81.6$ and $81.3 \%$, respectively.

The unbiased pairwise genetic distance showed that the lower values were obtained at intraspecies level of genera Halophila, Cymodocea and Halodule as 0.5, 0.66 and 0.61 , respectively. However, higher genetic distances were observed between intergeneric levels (Table 4) for all seagrass genera. Species of Halophila ovalis subsp. ovalis, H. ovata and H. ovalis subsp. ramamurthina showing subtle morphological variations recorded a genetically distinct relation with a genetic distance of $0.584,0.557$ and 0.5 , respectively.

The relationship among the different seagrass species was further subjected by PCoA which recorded the first three coordinates, accounting for $34.65,23.9$ and $19.72 \%$ of variance, with a total cumulative variance of $78.27 \%$. In this analysis, the majority of groupings followed the same pattern as depicted in the dendrogram with minor differences such as the genus belonging to Cymodocea and Halodule also being clustered together in the PCoA. However, the PCoA (Figure 3) showed a separation of the individuals into scattered form and grouping of individual species belonging to the same genus grouped together except $H$. beccarii.

The UPGMA dendrogram (Figure 4) generated by following the Nei's distance matrix revealed clear genetic relationship among the 14 seagrass species. The rooted dendrogram clustered the species within distinct groups according to their genus specificity. Interestingly, the dendrogram formed two distinctive clusters corresponding to Cymodoceaceae 


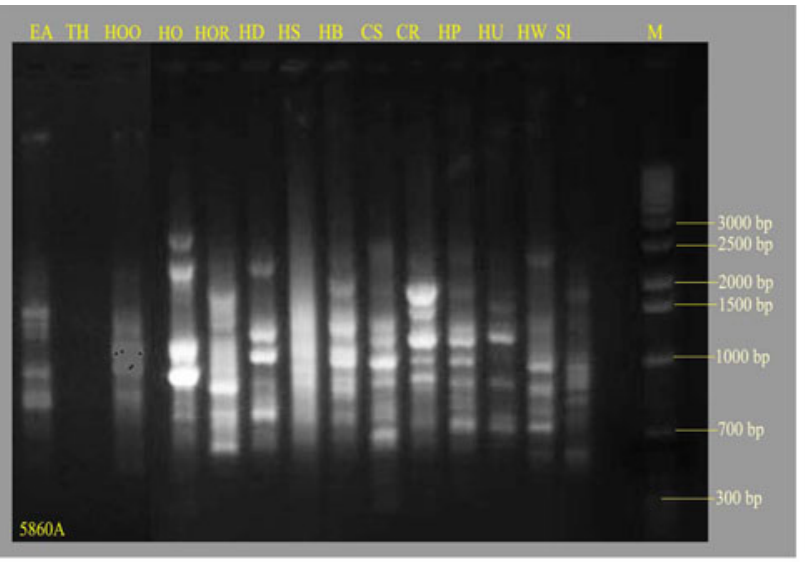

(a)

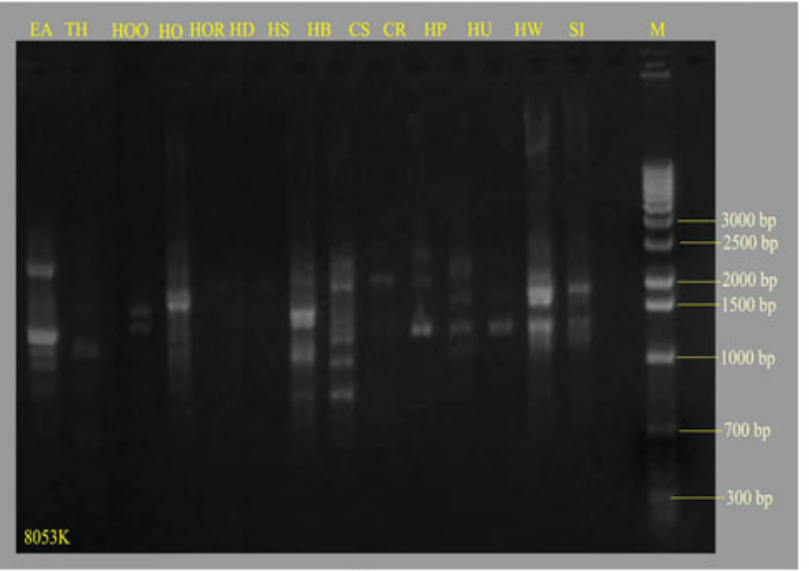

(b)

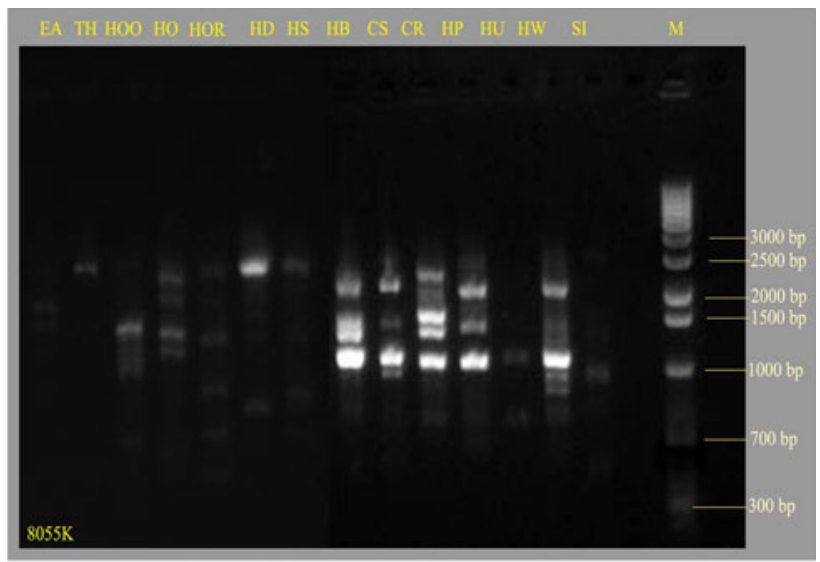

(c)

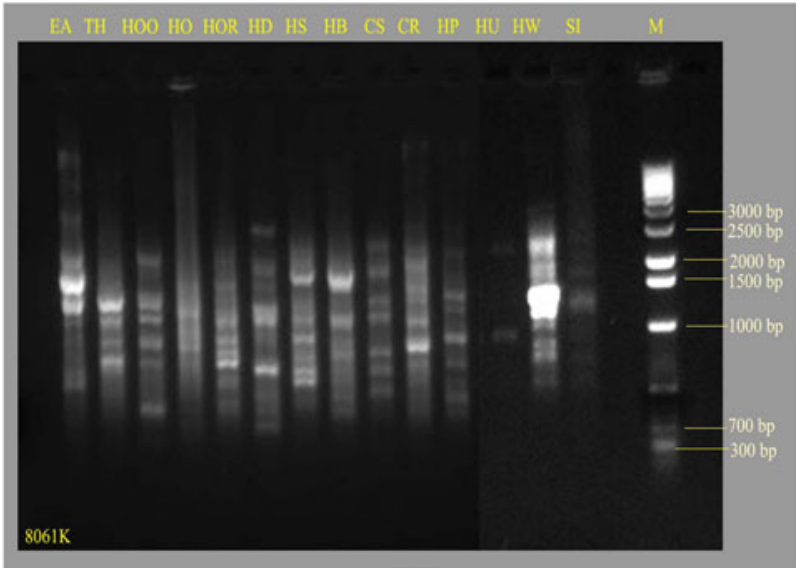

(d)

Fig. 2. The electropherogram of RAPD profiles for marine angiosperms of India using different primers: (A) $5860 A$, (B) $8053 \mathrm{~K},(\mathrm{C}) 8055 \mathrm{~K}$, (D) $8061 \mathrm{~K}$.

and Hydrocharitaceae families. Cluster I divided into three subclusters viz. (1) H. ovalis, $H$. ovata and $H$. ovalis subsp. ramamurthiana, (2) $H$. decipiens, $H$. beccarii and $H$. stipulacea and (3) E. acoroides and T. hemprichii. Cluster II divided into two subclusters (1) Cymodocea and (2) Halodule and Syringodium and further subdivided up to species level.

\section{DISCUSSIDN}

Results herein represent the first successful application of RAPD markers to characterize the genetic variations among the Indian seagrasses, which provide important functions in shallow coastal ecosystems. The RAPD survey of 14 seagrass species (Enhalus acoroides, Thalassia hemprichii, Halophila ovalis subsp. ovalis, $H$. ovalis subsp. ramamurthiana, $H$. ovata, $H$. decipiens, $H$. stipulacea, $H$. beccarii, Cymodocea serrulata, C. rotundata, Halodule pinifolia, $H$. uninervis, $H$. wrightii and Syringodium isoetifolium) demonstrates that the seagrasses display a wide range of genetic diversity between genera and registers close similarity between intraspecies of genus Halophila, Cymodocea and Halodule which are critical in discriminating the species through conventional means.

Primers used to generate the RAPD profile for each seagrass recorded $70.3 \%$ polymorphic loci (292) confirming the uniqueness of genotypes of different seagrasses. Waycott (1995) used RAPD markers to determine genetic variation and clonality with the seagrass Posidonia australis, four primers identified 45 loci which includes $56 \%$ polymorphic and five RAPD primers used on Florida T. testudinum produced 29 polymorphic loci (Kirsten et al., 1998). Micheli et al. (2005) have reported $80 \%$ of polymorphism within the population of a $P$. oceanica bed at Punta Mesco. However, in the present study some of the primers such as $3003 \mathrm{~A}$, $3010 \mathrm{~A}$ and $5852 \mathrm{~A}$ are capable of showing more than 30 polymorphic loci in Indian seagrasses. This confirms the efficiency of selected primers in distinguishing the genetic variability within Indian seagrasses.

Among the 10 primers used $3003 \mathrm{~A}, 3010 \mathrm{~A}, 5858 \mathrm{~A}$ and $8055 \mathrm{~K}$ are the key primers capable of distinguishing all the Indian seagrasses and proved to be quite powerful in detecting a high degree of polymorphism. However, the present study carried out with single populations of species warrants further tests with different populations so as to check the consistency of the primers in showing the polymorphism. Moreover, polymorphic variation was obtained from different species to show the genetic variability among different species. The polymorphic alleles recorded in all the tested species encourages further work with these primers to finalize the taxonomic tools.

Among the different primers used for the present study primers such as $5852 \mathrm{~A}$ and $5854 \mathrm{~A}$ are capable of showing more DNA bands (62 and 55 respectively) than the others. Unfortunately the percentage of polymorphism was very 
Table 4. Nei's unbiased pair-wise genetic distance values recorded for 14 Indian seagrass species.

\begin{tabular}{|c|c|c|c|c|c|c|c|c|c|c|c|c|c|c|}
\hline & EA & TH & HOO & HO & HOR & HD & HS & HB & CS & CR & HP & HU & HW & SI \\
\hline EA & $* * *$ & 0.4 & 0.4 & 0.281 & 0.3 & 0.187 & 0.266 & 0.4 & 0.126 & 0.059 & 0.187 & 0.161 & 0.089 & 0.1 \\
\hline $\mathrm{TH}$ & & $* * *$ & 0.392 & 0.28 & 0.304 & 0.16 & 0.173 & 0.097 & 0.122 & 0.075 & 0.12 & 0.125 & 0.075 & 0.086 \\
\hline $\mathrm{HOO}$ & & & $* * *$ & 0.584 & 0.557 & 0.276 & 0.262 & 0.321 & 0.062 & 0.117 & 0.123 & 0.126 & 0.088 & 0.065 \\
\hline $\mathrm{HO}$ & & & & $* * *$ & 0.5 & 0.281 & 0.266 & 0.218 & 0.095 & 0.089 & 0.031 & 0.064 & 0.059 & 0.033 \\
\hline HOR & & & & & $* * *$ & 0.466 & 0.392 & 0.313 & 0.033 & 0.095 & 0.1 & 0.137 & 0.095 & 0.107 \\
\hline HD & & & & & & $* * *$ & 0.5 & 0.436 & 0.063 & 0.059 & 0.125 & 0.161 & 0.179 & 0.133 \\
\hline HS & & & & & & & $* * *$ & 0.588 & 0.067 & 0.063 & 0.066 & 0.103 & 0.095 & 0.107 \\
\hline $\mathrm{HB}$ & & & & & & & & $* * *$ & 0.111 & 0.068 & 0.072 & 0.037 & 0.034 & 0.039 \\
\hline CS & & & & & & & & & $* * *$ & 0.666 & 0.412 & 0.327 & 0.393 & 0.305 \\
\hline CR & & & & & & & & & & $* * *$ & 0.507 & 0.553 & 0.457 & 0.444 \\
\hline HP & & & & & & & & & & & $* * *$ & 0.709 & 0.567 & 0.4 \\
\hline $\mathrm{HU}$ & & & & & & & & & & & & $* * *$ & 0.615 & 0.448 \\
\hline HW & & & & & & & & & & & & & $* * *$ & 0.698 \\
\hline SI & & & & & & & & & & & & & & $* * *$ \\
\hline
\end{tabular}

low (54.8 and 50.9\% respectively). Such primers are key to confirming the identity of Indian seagrasses in tracking the origin of the plant samples. Based on the performances of different primers in resolving the genetic differences in seagrasses, it is evident that during the growth stage, the different markers (Mariette et al., 2002) show differing RAPD results for the same species; under these conditions selection of plants and experimental consistency are key in the successful application of RAPD techniques in seagrass taxonomy. The present result found 0.031-0.709 pairwise genetic variability among Indian seagrasses. Waycott \& Barnes (2001) clearly stated that the genetic diversity of a seagrass population ranges from zero to high for different species and populations; this warrants the need for testing these primers at population level. Waycott \& Barnes (2001) also emphasized that several studies to date are inadequately sampled and this often reduces the interpretability of the existing results. Hence in the present study the utmost care was taken for sampling, Samples were collected based on the following criteria, (1) should be from a single extension, (2) fresh young leaves in first three nodes only collected and (3) leaves attached with epiphytes were removed.

Throughout the world the systematic placement of the Halophila section has been based on morphology (Eiseman

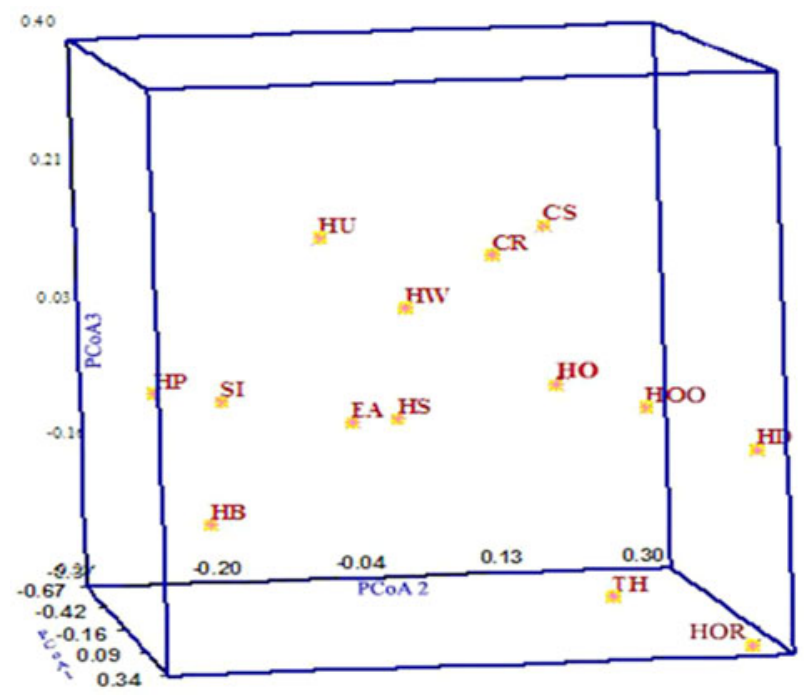

Fig. 3. Principal coordinate analysis of the 14 Indian seagrass species.
\& McMillan, 1980) and isozyme banding (McMillan \& Williams, 1980) characteristics. In India, the genus Halophila is represented by six species (Halophila ovalis subsp. ovalis, $H$. ovalis subsp. ramamurthiana, $H$. ovata, $H$. decipiens, $H$. stipulacea and $H$. beccarii). Subtle morphological and vegetative differences (number of cross veins, seeds, shape of the leaf lamina etc.) among Halophila ovalis, $H$. ovalis subsp. ramamurthiana and $H$. ovata make identification challenging and often results in misidentification. The present RAPD study showed clear genetic distance between the species (0.584, 0.557 and 0.5, respectively). Similarly, Smith et al. (1997) found a genetic similarity of 0.6 and 0.66 for $H$. decipiens and $H$. johnsonii which means a genetic distance of 0.4 and 0.44 . This indicates that RAPD markers provide more reliable results than the morphological characters which are able to resolve the distinctions of closely related species (Pau \& Othman, 2002). Further in depth studies of these three species with different populations may result in identification of the possible parent species of the subspecies $H$. ovalis subsp. ramamurthiana and also help to resolve the relatedness of the species with $H$. ovalis subsp. ovalis and $H$. ovata. Recently, Nguyen et al. (2013) studied Amplified Fragment Length Polymorphism (AFLP) among the subspecies of $H$. ovalis subsp. ovalis, $H$. ovata and $H$. ovalis subsp. ramamurthiana and they concluded that $H$. ovalis subsp. ramamurthiana was genetically different between species as well as geography. It is evident that the genetic structure of the plant populations could enable elucidation of the evolutionary linkages, mutation, genetic drift, mating system, gene flow etc. (Slatkin, 1987; Schaal et al., 1998). Even the PCoA and UPGMA dendrogram showed similar pattern of variation between these three species. Other Halophila species have distinct vegetative characters, such as serrulate leaf margin and stiff hairs on abaxial side of the leaf $(H$. decipiens), serrulate leaf margin and sheathed leaf base (H. stipulacea) and more than 6 leaves per node $(H$. beccarii). The Halophila group showed a close similarity in DNA fingerprints among each other and clustered together in a single clade in the dendrogram. It confirms that the RAPD markers are capable of bringing out the interspecies differences within the genera. The PCoA plot also clearly distinguished these species into separate entities comparable to the UPGMA dendrogram.

The genetic distance between Enhalus acoroides and Thalassia hemprichii was 0.4 , the PCoA plot separated these 


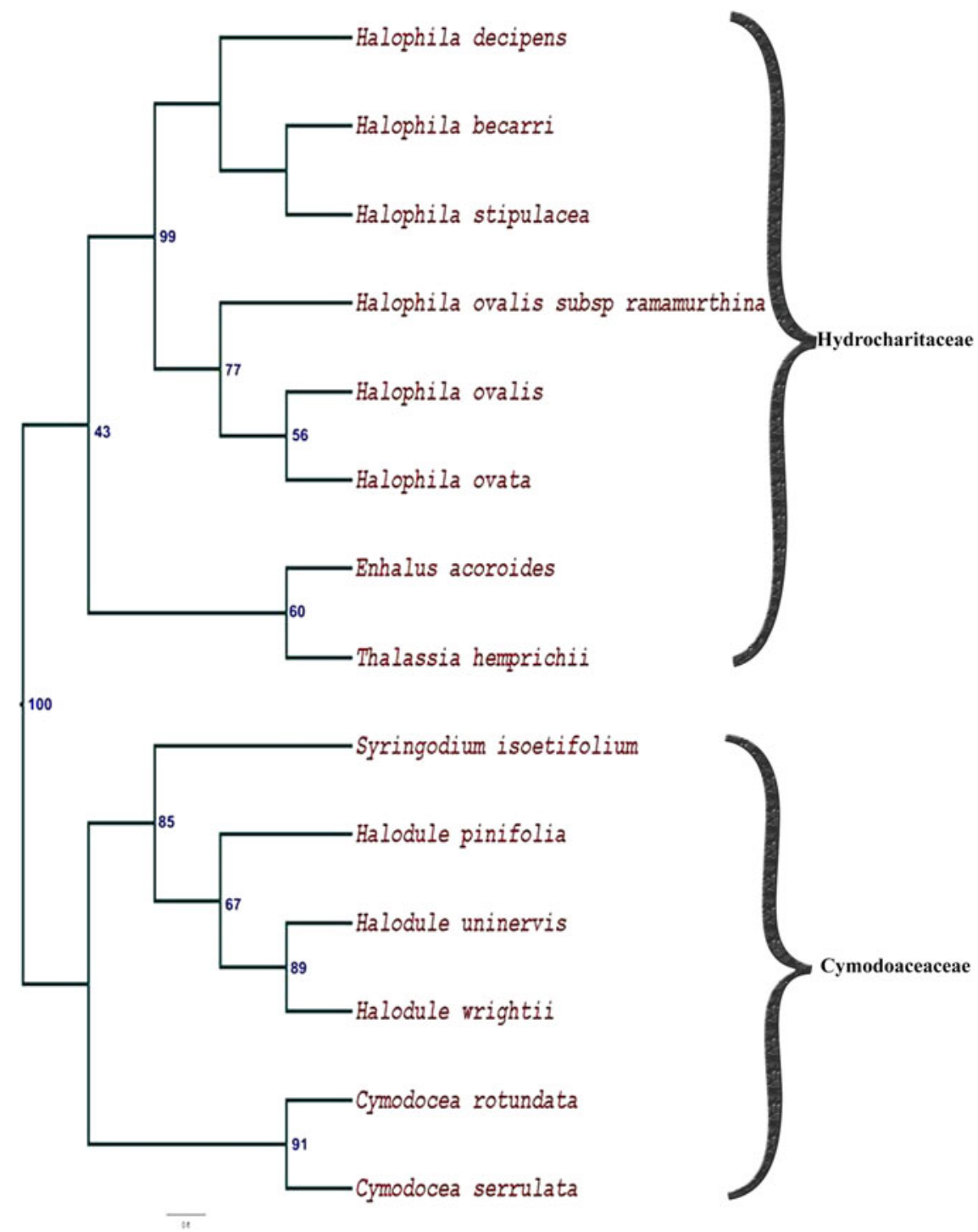

Fig. 4. Dendrogram showing genetic relationships among the 14 Indian seagrass species. The neighbour-joining method (FreeTreeware) was applied to an average 'taxonomic' distance matrix among the individuals.

two genera from each other, and the UPGMA dendrogram grouped these plants in one cluster indicating the relatedness of these two species. Isozyme studies of three Hydrocharitaceae genera also enable to distinguish these species, but Enhalus is more similar to Thalassia than to Halophila (McMillan, 1982). Even the morphological distinctness of Halophila having petiolate leaves is a clear character distinguishing the other two genera of the marine Hydrocharitaceae family which are apetiolate in nature.

The sympatric species C. serrulata and C. rotundata have a close similarity in DNA fingerprinting and shared a common node in UPGMA dendrogram with a genetic distance of 0.666 . The heterogeneous RAPD pattern found between the Cymodocea species indicates that the leaf morphometrics such as difference in width of the leaf lamina (3-6 mm for C. rotundata and 4-10 $\mathrm{mm}$ for C. serrulata), serrulation in the apex (rarely serrulate in case of $C$. rotundata and serrulate in $C$. serrulata), number of nerves (9-14 for C. rotundata and 12-22 for C. serrulata) were associated with an increased genetic variation between the species. Alberto et al. (2001) also applied RAPD techniques in C. nodosa from six populations of the Atlantic sea using 28 random primers and found genetic homogeneity among C. nodosa populations of the Atlantic sea, which means the genetic characters of the same species of the same regions are more homogeneous in nature, but this is not common to all species of seagrasses. However, Rotini et al. (2011) reported that RAPD showed low genetic variability in $P$. oceanica from Santa Marinella seagrass meadows; whereas, Nguyen et al. (2014) analysed genetic diversity of seagrasses based on microsatellite markers and revealed that the genetic variability in the Western Pacific is higher than in the Eastern Indian ocean.

The genetic variation between the Halodule species of $H$. pinifolia (no lateral teeth), H. uninervis (tridentate leaf tip) and $H$. wrightii (bidentate leaf tip) conventionally can be identified by leaf tip morphology (Den Hartog, 1970) but the fragile nature of leaves means that they easily break away under natural conditions and can result in a taxonomic paradigm. The genetic distance of $0.709,0.567$ and 0.615 recorded for these species gives a clear clue for differentiating the species without any ambiguity. 
The high level of similarity at intraspecies level has also shown that all the samples of each species are monophyletic. It can be inferred from the present investigation that the RAPD technique is a useful tool for the analysis of genetic diversity among the Indian seagrasses and can be used as the tool to resolve the taxonomic issues of Indian seagrasses. Primers $3003 \mathrm{~A}, 3010 \mathrm{~A}$ and $5852 \mathrm{~A}$ are the key primers that can be used as a tool for identifying the genetic and species variations after testing the primers at different populations of the same species.

\section{ACKNOWLEDGEMENTS}

The authors thank Dr K. Kathiresan, Director and Dean, and Dr T. Balasubramanian, former Director and Dean, CAS in Marine Biology, Faculty of Marine Sciences and authorities of Annamalai University for providing facilities and support. The contents and views reported in this manuscript are of individual authors and do not reflect the views of institutions to which they belong.

\section{FINANCIAL SUPPORT}

E. Dilipan is thankful to the DAAD and the Leibniz University Hannover, for financial support through 'A new passage to India' with which the present study was carried out.

\section{REFERENCES}

Alberto F., Mata L. and Santos R. (2001) Genetic homogeneity in the seagrass Cymodocea nodosa at its northern Atlantic limit revealed through RAPD. Marine Ecological Progress Series 221, 299-301.

Angel R. (2002) Genetic diversity in Halodule wrightii using Random Amplified Polymorphic DNA. Aquatic Botany 74, 165-174.

Avise J.C. (1994) Molecular markers, natural history, and evolution. New York: Chapman and Hall, 511 pp.

Bai Y., Huang C.C., Hulst R.V., Meijer Dekens F., Bonnema G. and Lindhout P. (2003) QTLs for tomato powdery mildew resistance (Oidium lycopersici) in Lycopersicon parviflorum G1.1601 co-localize with two qualitative powdery mildew resistance genes. Molecular Plant-Microbe Interactions 16, 169-176.

Callejas C., Luskova V. and Ochando M.D. (2004) A contribution to the genetic characterization of some species of the genus Gobia (Cyprinidae). Folia Zoology 53, 433-436.

Capiomont A., Sandmeier M., Caye G. and Meinesz A. (1996) Enzyme polymorphism in Posidonia oceanica, a seagrass endemic to the Mediterranean. Aquatic Botany 54, 265-277.

Chalmers K.J., Cambell A.W., Kretschmer J., Karakousis A., Henschke P.H., Pierens S., Harker N., Pallotta M., Cornish G.B., Shariflou M.R., Rampling L.R., McLauchlan A., Daggard G., Sharp P.J., Holton T.A., Sutherland M.W., Appels R. and Langridge P. (2001) Construction of three linkage maps in bread wheat, Triticum aestivium. Australian Journal of Agricultural Research 52, 1089-1119.

Clark A.G. and Lanigan C.M.S. (1993) Prospects for estimating nucleotide divergence with RAPDs. Molecular Biology and Evolution 10, $1096-1111$.

Das B.K., Jena R.C. and Samal K.C. (2009) Optimization of DNA isolation and PCR protocol for RAPD analysis of banana/plantain (Musa spp.). International Journal of Agricultural Sciences 1, 21-25.
Davis J.L., Childers D.L. and Kuhn D.N. (1999) Clonal variation in a Florida Bay Thalassia testudinum meadow: molecular genetic assessment of population structure. Marine Ecological Progress Series 186, $127-136$.

De Heij H. and Nienhuis P.H. (1992) Intraspecific variation on isozyme patterns of phenotypically separated populations of Zostera marina $\mathrm{L}$. in the south-western Netherlands. Journal of Experimental Marine Biology and Ecology 161, 1-14.

den Hartog C. (1970) The seagrasses of the world. Amsterdam: North-Holland Publishing, 275 pp.

Dong Y.H., Gituru R.W. and Wang Q.F. (2010) Genetic variation and gene flow in the endangered aquatic fern Ceratopteris pteridoides in China and conservation implications. Annales Botanici Fennici 47, $34-44$.

Eiseman N.J. and McMillan C. (1980) A new species of seagrass, Halophila johnsonii, from the Atlantic coast of Florida. Aquatic Botany 9, 15-19.

Grosberg R.K., Levitan D.R. and Cameron B.B. (1996) Characterization of genetic structure and genealogies using RAPD-PCR markers: a random primer for the novice and nervous. In Ferraris J.D. and Palumbi S.R. (eds) Molecular zoology: advances, strategies and protocols. New York, NY: John Wiley and Sons, pp. 67-100.

Jones C.T., Gemmil C.E.C. and Pilditch C.A. (2008) Genetic variability of New Zealand seagrass (Zostera muelleri) assessed at multiple spatial scales. Aquatic Botany 88, 39-46.

Jover M.A., Del Castillo-Agudo L., Garcia-Carrascosa M. and Segura J. (2003) Random amplified polymorphic DNA assessment of diversity in western Mediterranean populations of the seagrass Posidonia oceanica. American Journal of Botany 90, 364-369.

Kannan L. and Thangaradjou T. (2006) Identification and assessment of biomass and productivity of seagrasses. In Proceedings of the national training workshop on marine and coastal biodiversity assessment for conservation and sustainable utilization, SDMRI Publication. pp. 9-15.

Kirsten J.H., Dawes C.J. and Cochrane B.J. (1998) Randomly amplified polymorphism detection (RAPD) reveals high genetic diversity in Thalassia testudinum Banks ex König (Turtlegrass). Aquatic Botany $61,269-287$

Lambert D.M. and Millar C.D. (1995) DNA science and conservation. Pacific Conservation Biology 2, 21-38.

Laushman R.H. (1993) Population genetics of hydrophilous angiosperms. Aquatic Botany 44, 147-158.

Lim S.H., Teng P.C.P. and Lee Y.H. (1999) RAPD analysis of some species in the genus Vanda (Orchidaceae). Annals of Botany 83, $193-196$.

Lucas C., Thangaradjou T. and Papenbrock J. (2012) Development of a DNA barcoding system for seagrasses: successful but not simple. PLoS ONE 7, 1-12.

Mahmood T., Iqbal A., Nazar N., Naveed I., Abbasi B.H. and Naqvi S.M.S. (2011) Assessment of genetic variability among selected species of Apocynaceae. Biologia 66, 64-67.

Mariette S., Le Corre V., Austerlitz F. and Kremer A. (2002) Sampling within the genome for measuring within-population diversity: tradeoffs between markers. Molecular Ecology 11, 1145-1156.

Martin J.P. and Hernandez B.J.E. (2000) Genetic variation in the endemic and endangered Rosmarinus tomentosus Huber-Morath and Maire (Labiatae) using RAPD markers. Heredity 85, 434-443.

McMillan C. (1981) Morphological variation and isozymes under laboratory conditions in Cymodocea serrulata. Aquatic Botany 10, 356-370.

McMillan C. (1982) Isozymes in seagrasses. Aquatic Botany 14, 231-243. 
McMillan C. and Williams S.C. (1980) Systematic implications of isozymes in Halophila section Halophila. Aquatic Botany 9, 21-31.

Micheli C., Paganin P., Peirano A., Caye G., Meinesz A. and Bianchi C.N. (2005) Genetic variability of Posidonia oceanica (L.) Delile in relation to local factors and biogeographic patterns. Aquatic Botany $82,210-221$.

Nei M. (1978) Estimation of average heterozygosity and genetic distance from a small number of individuals. Genetics 89, 583-590.

Nei M. (1987) Molecular evolutionary genetics. New York, NY: Columbia University Press, pp. $361-364$.

Nei M. and Li W. (1979) Mathematical model for studying genetic variation in terms of restriction endonucleases. Proceedings of the National Academy of Sciences USA 76, 5269-5273.

Nguyen X.V., Thangaradjou T. and Papenbrock J. (2013) Genetic variation among Halophila ovalis (Hydrocharitaceae) and closely related seagrass species from the coast of Tamil Nadu, India - an AFLP fingerprint approach. Systematics and Biodiversity 11, 467-476.

Nguyen X.V., Detcharoen M., Tuntiprapas P., Soe-Htun U., Sidik B.J. Harah Z.M., Prathep A. and Papenbrock J. (2014) Genetic species identification and population structure of Halophila (Hydrocharitaceae) from the Western Pacific to the Eastern Indian Ocean. BMC Evolutionary Biology 14, 92.

Page R.D. (1996) TREEVIEW: an application to display phylogenetic trees on personal computers. Computer Applications in the Biosciences 12, 357-358.

Pau M.S. and Othman A.S. (2002) Randomly amplified polymorphic DNA analysis of seagrass, Halophila ovalis. In Proceedings of the 4 th IMT-GT UNINET Conference, Penang, Malaysia, pp. 1-5.

Procaccini G. and Mazzella L. (1996) Genetic variability and reproduction in two Mediterranean seagrasses. In Kuo J., Phillips R.C., Walker D.I. and Kirkman H. (eds) Seagrass biology: proceedings of an international workshop, Rottnest Island, Western Australia. SCIENCES UWA, pp. 85-92.

Procaccini G., Mazzella L., Alberte R.S. and Les D.H. (1999) Chloroplast tRNA Leu (UAA) intron sequences provide phylogenetic resolution of seagrass relationships. Aquatic Botany 62, 269-283.

Ramamurthy K., Balakrishnan N.P., Ravikumar K. and Ganesan R. (1992) Seagrasses of Coromandel coast, India. Flora of India - Series 4, Botanical Survey of India, $80 \mathrm{pp}$.

Randall S.A., Suba G.K., Procaccini G., Zimmerman R.C. and Fain S.R. (1994) Assessment of genetic diversity of seagrass population using DNA fingerprinting: implication for population stability and management. Proceedings of the National Academy of Sciences USA 91, $1049-1053$.

Reusch T.B.H. (2001) Fitness-consequences of geitonogamous selfing in a clonal marine angiosperm (Zostera marina). Journal of Evolutionary Biology 14, 129-138.
Reusch T.B.H. (2002) Microsatellites reveal high population connectivity in eelgrass (Zostera marina) in two contrasting coastal areas. Limnology and Oceanography 47, 78-85.

Reynolds L.K., Waycott M., McGlathery K.J., Orth R.J. and Zieman J.C. (2012) Eelgrass restoration by seed maintains genetic diversity: case study from a coastal bay system. Marine Ecological Progress Series $448,223-233$.

Rohlf F.J. (2000) NTSYSpc. Numerical taxonomy and multivariate analysis system. Version 2.01. Setauket, NY: Exeter software.

Rotini A., Micheli C., Valiante L. and Migliore L. (2011) Assessment of Posidonia oceanica (L.) Delile conservation status by standard and putative approaches: the case study of Santa Marinella meadow (Italy, W Mediterranean). Open Journal of Ecology 1, 48-56.

Schaal B.A., Hayworth D.A., Olsen K.M., Rauscher J.T. and Smith W.A. (1998) Phylogenetic studies in plants: problems and prospects. Molecular Ecology 7, 465-474.

Slatkin M. (1987) Gene flow and the geographic structure of populations. Science 236, 787-792.

Smith J.J., McMillan C., Kenworthy W.J. and Bird K. (1997) Flowering and genetic banding patterns of Halophila johnsonii and conspecifics. Aquatic Botany 59, 323-331.

Storchova H., Hrdlickova R., Chrtek J., Tetera M. and Fitze D. (2000) An improved method of DNA isolation from plants collected in the field and conserved in saturated $\mathrm{NaCl} / \mathrm{CTAB}$ solution. Taxon 49, $79-84$.

Viccini L.F., Souza da Costa D.C., Machado M.A. and Campos A.L. (2004) Genetic diversity among nine species of Lippia (Verbenaceae) based on RAPD markers. Plant Systematics and Evolution 246, 1-8.

Waycott M. (1995) Assessment of genetic variation and clonality in the seagrass Posidonia australis using RAPD and allozyme analysis. Marine Ecological Progress Series 116, 289-295.

Waycott M. (1998) Genetic variation, its assessment and implications to the conservation of seagrasses. Molecular Ecology 7, 793-800.

and

Waycott M. and Barnes P.A.G. (2001) AFLP diversity within and between populations of the Caribbean seagrass Thalassia testudinum (Hydrocharitaceae). Marine Biology 139, 1021 - 1028.

\section{Correspondence should be addressed to:}

T. Thangaradjou

Centre of Advanced Study in Marine Biology, Annamalai University, Parangipettai - 608 502, Cuddalore Dt., Tamilnadu, India email: umaradjou@yahoo.com 